\title{
Buku Cerita Rakyat Riau Ketobong Keramat Berbasis Markerless Augmented Reality (AR) dengan Teknik User-Defined Target
}

\author{
Michael $^{1}$, Anggy Trisnadoli ${ }^{2 *}$, Rahmat Suhatman ${ }^{3}$ \\ Jurusan Teknologi Informasi, Politeknik Caltex Riau \\ michaelmushigen@alumni.pcr.ac.id ${ }^{1}$, anggy@pcr.ac.id ${ }^{2}$, rahmat@pcr.ac.id ${ }^{3}$
}

\begin{tabular}{l}
\hline \hline Article Info \\
\hline Article history: \\
Received 2019-09-16 \\
Revised 2019-09-30 \\
Accepted 2019-11-25
\end{tabular}

\begin{abstract}
Folklore is a story that has been passed down from generation to generation, where each region has its own folklore. In Pelalawan District, there's a folklore called Ketobong Keramat, where the folklore telling a story about a Magical Doctor who was willing to sacrifice his personal interests to help the King of Pelalawan. According to Malay Culture Study and Development Center, folklore is a cultural property that is not given enough attention. This can be seen in many folklore from certain regions which are quite popular but not yet known by the people in other regions. Therefore, in this final project, the Ketobong Keramat Augmented Reality application was made to the folklore. The method used in this application is the Markerless Augmented Reality Method using the User Defined Target technique, so that the Augmented Reality object can be displayed on the surface chosen by the user. Through the development of the Ketobong Keramat Augmented Reality application, it is hoped that it can increase community interest in undertaking excavations and disseminating folklore in the archipelago, as well as implementing technology on other folklore that is not yet widely known by the people of Indonesia.
\end{abstract}

\section{Pendahuluan}

Dewasa ini, perkembangan zaman dan teknologi belum memberikan dampak yang cukup positif terhadap cerita-cerita rakyat yang ada di nusantara. Cerita rakyat yang tersebar di berbagai pelosok nusantara merupakan kekayaan budaya yang masih kurang diperhatikan. Hal ini tampak pada banyaknya cerita-cerita rakyat dari daerah tertentu yang cukup populer tetapi belum dikenal oleh masyarakat di daerah lain, kecuali beberapa saja seperti Malin Kundang, Bawang Merah dan Bawang Putih, Sangkuriang, dan lain-lain. Permasalahan ini tidak berkaitan dengan pemilik cerita rakyat, tetapi berkaitan dengan kurangnya upaya penggalian dan publikasi secara nasional dan global oleh pihak-pihak yang berkompeten [1].

Augmented Reality adalah teknologi yang menggabungkan antara dunia nyata dengan dunia virtual baik dalam bentuk 2D ataupun $3 \mathrm{D}$, sehingga mengurangi batas antara dunia nyata dengan dunia virtual tersebut. Augmented Reality memungkinkan pembaca untuk melakukan interaksi dengan dunia digital, dimana pembaca dapat melihat animasi yang berjalan dari berbagai sudut pandang, sehingga memungkinkan pembaca untuk memahami isi cerita dengan mudah. Oleh karena itu, penggunaan Augmented Reality diimplementasikan pada buku cerita ini.

Pengimplementasian Markerless Augmented Reality yang menggunakan teknik User-Defined Target ini dilakukan terhadap buku cerita rakyat Ketobong Keramat [2]. Banyaknya penelitian terdahulu yang mengimplementasikan Augmented Reality dijadikan sebagai referensi, sehingga perlu dilakukan studi pustaka yang bertujuan untuk mengidentifikasikan kesenjangan (identify gaps), menghindari pembuatan ulang (reinventing the wheel), mengidentifikasikan metode yang pernah dilakukan, meneruskan penelitian sebelumnya, serta mengetahui spesialisasi yang orang lain fokuskan pada penelitiannya.

Penelitian implementasi Augmented Reality (AR) pada fosil purbakala di Museum Geologi Bandung [3]; penelitian lain bagaimana merepresentasikan objek Candi Prambanan pada buku interaktif ARca; merepresentasikan objek pada maps dengan teknologi markless [5] serta penelitian yang menampilkan objek 3 dimensi beserta gerakan dan suara dari objek yang sudah menjadi marker [6]; selain itu penelitian aplikasi Markerless Augmented Reality sebagai media 
pengenalan dan pembelajaran huruf Lontara [7] serta pengenalan tata surya [8]; penelitian bagaimana menampilkan animasi karakter 2 dimensi pada buku [9] dengan marker berbentuk background dari animasi Malin Kundang [10]; penelitian bagaimana mengembangkan Markerless Augmented Reality yang memanfaatkan fungsi Giroskop untuk menunjukkan posisi Dewata Nawa Sanga, serta menampilkan animasi 3 dimensi beserta informasi tentang Dewata Nawa Sanga [11]; penelitian bagaimana memunculkan objek 3D diatas marker hewan khusus pada permukaan magic book memanfaatkan Markerless Augmented Reality [12]; penelitian bagaiamana menampilkan gambar dan teks, ataupun video dari objek koleksi museum Kalimantan Barat dengan memanfaatkan Markerless Augmented Reality [13]; penelitian bagaimana memanfaatkan Markerless Augmented Reality beserta Global Positioning System untuk membangun aplikasi yang mampu menampilkan titik lokasi gedung-gedung di Universitas Lampung, berfungsi sebagai media pengenalan gedunggedung tersebut [14]; penelitian terakhir mengembangkan aplikasi ARBrosur memanfaatkan Markerless Augmented Reality yang mampu membaca gambar pada brosur perumahan yang sudah diregistrasi aplikasi, untuk menampilkan animasi 3D perumahannya [15].

Pada pengembangannya, aplikasi ini akan menggunakan metode User-Defined Target, User-Defined Target adalah Image Target yang dibuat saat runtime dari bingkai kamera yang dipilih oleh pengguna. User-Defined Target memungkinkan seorang end user untuk memilih sebuah gambar saat runtime. Dengan demikian, pengguna merasakan AR "kapan saja, di mana saja" dengan memilih gambar (seperti foto, sampul buku atau poster) dari lingkungan terdekatnya tanpa harus membawa-bawa target yang telah ditentukan [16].

Augmented Reality (AR) adalah sebuah teknik penggabungan objek antara dunia maya dan dunia nyata. Teknik ini bekerja berdasarkan marker yang ditempatkan di posisi tertentu. Marker ini berupa citra (gambar) yang umumnya berwarna hitam putih yang diberi garis pinggir berwarna hitam. Marker ini nantinya dapat digerakkan secara perlahan, sehingga objek maya akan mengikuti pergerakan marker ini [17].

Pada penelitian ini, Markerless Based Augmented Reality akan diimpelementasikan untuk cerita rakyat yang berjudul Ketobong Keramat, yang menceritakan tentang seorang bomo (tabib) sakti yang melayani rajanya. Alasan pengimplementasian Markerless Based Augmented Reality adalah jika aplikasi Augmented Reality menggunakan marker untuk memunculkan animasi, akan menyebabkan aplikasi tersebut menjadi ketergantungan, karena aplikasi hanya dapat dijalankan jika marker tersedia. Dengan tidak memerlukan penggunaan marker, pengimplementasian aplikasi Augmented Reality terhadap buku cerita rakyat Ketobong Keramat memungkinkan pembaca dapat menikmati animasi buku cerita rakyat Ketobong Keramat dalam berbagai sudut dengan lebih leluasa.
Teknik yang diimplementasikan pada penelitian Markerless Based Augmented Reality ini adalah teknik UserDefined Target dimana teknik yang digunakan dapat mempermudah penggunaan aplikasi, karena pengguna dapat menentukan objek yang akan digunakan sebagai tempat menampilkan objek Augmented Reality secara bebas.

Harapan dari penelitian ini adalah untuk meningkatkan minat baca, baik anak-anak, remaja, maupun orang dewasa, sehingga tertarik untuk menggali lebih dalam cerita-cerita rakyat nusantara serta meningkatkan minat seseorang dalam menyebarluaskan, serta membudidayakan cerita-cerita rakyat yang ada di nusantara.

\section{Metodologi Penelitian}

Metode penelitian dijelaskan pada tahapan-tahapan penelitian sebagai berikut.

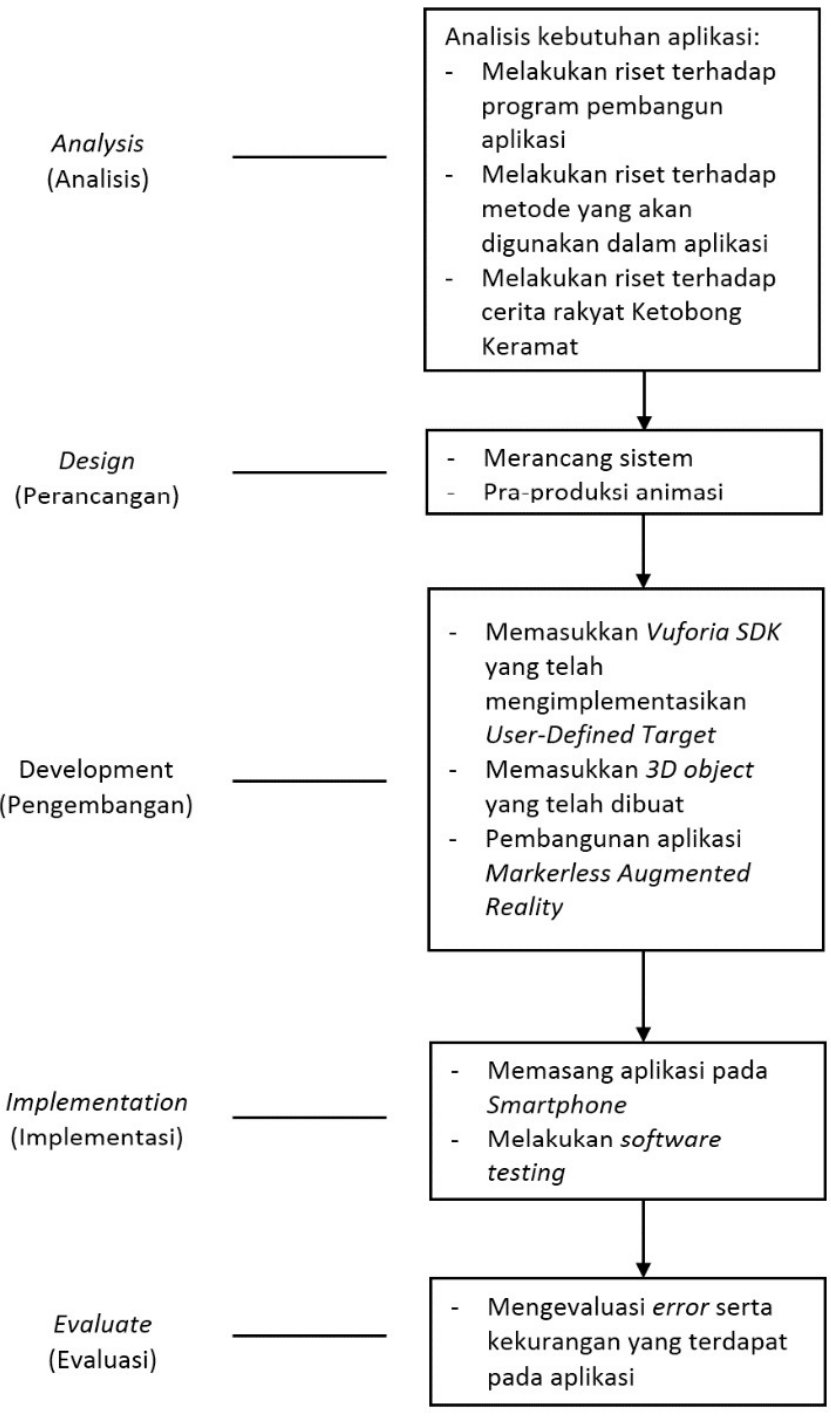

Gambar 1. Diagram Pengembangan AR Ketobong Keramat

Tahap penelitian dalam pembangunan aplikasi Augmented Reality Ketobong Keramat dimulai dengan melakukan analisis terhadap hal-hal yang dibutuhkan untuk membangun 
aplikasi. Setelah menyelesaikan analisis kebutuhan, dilanjutkan dengan melakukan perancangan terhadap sistem serta pra-produksi animasi.

Tahap pra-produksi animasi yang dijalani adalah melakukan brainstorming terhadap ide cerita, lalu dilanjutkan dengan penyusunan skenario, lalu melakukan brainstorming terhadap objek-objek yang akan digunakan dalam animasi.

Pada aplikasi, metode pengujian yang digunakan adalah Black Box Testing untuk melakukan pengujian fungsional aplikasi. Sedangkan animasi divalidasi oleh orang yang mengetahui seluk beluk cerita Ketobong Keramat. Selain kedua pengujian tersebut, juga dilakukan umpan balik pengguna terhadap aplikasi yang telah dibangun, serta dilakukan pengujian Technical untuk mengetahui kemampuan dari hardware dalam menjalankan aplikasi.

Pengujian Black Box Testing pada aplikasi Augmented Reality Ketobong Keramat akan diujikan kepada pengguna yang telah diberikan test case untuk melakukan test fungsionalitas dari aplikasi Augmented Reality Ketobong Keramat.

Validasi Objek Ketobong Keramat ini dilakukan di Lembaga Adat Melayu Riau, dimana penguji akan melakukan pemeriksaan terhadap detail dari objek animasi yang terdapat pada aplikasi Augmented Reality Ketobong Keramat untuk memastikan kesesuaian objek animasi terhadap cerita rakyat Ketobong Keramat.

Umpan balik pengguna berfungsi untuk mengetahui pendapat pengguna terhadap aplikasi yang digunakannya. Umpan balik pengguna dilakukan dengan mengumpulkan 30 orang yang bersedia untuk mencoba aplikasi di kampus. Setelah itu, dilakukan pembagian aplikasi yang telah dibangun kepada 30 orang tersebut. Setelah mencoba aplikasi, para pengguna diberikan form yang berisikan pertanyaanpertanyaan untuk memperoleh pendapat pengguna terhadap aplikasi yang telah dibangun.

Pengujian Technical dilakukan untuk mengetahui kemampuan dari hardware dalam menjalankan aplikasi, serta untuk mengetahui kecepatan aplikasi dalam merespon pengguna. Beberapa hal yang diuji adalah sebagai berikut:

- jenis permukaan, jarak kamera, serta pencahayaan terhadap permukaan untuk memunculkan animasi

- waktu yang dibutuhkan aplikasi untuk memunculkan animasi

\section{HASIL DAN PEMbahasan}

Hasil dari penelitian ini adalah sebuah aplikasi Augmented Reality yang dibuat menggunakan program Unity untuk menampilkan animasi memanfaatkan Markerless Augmented Reality serta aplikasi Blender untuk melakukan modelling hingga animating dari animasi. Secara umum gambaran aplikasi AR yang telah dikembangkan dapat dilihat pada Gambar 2 berikut.

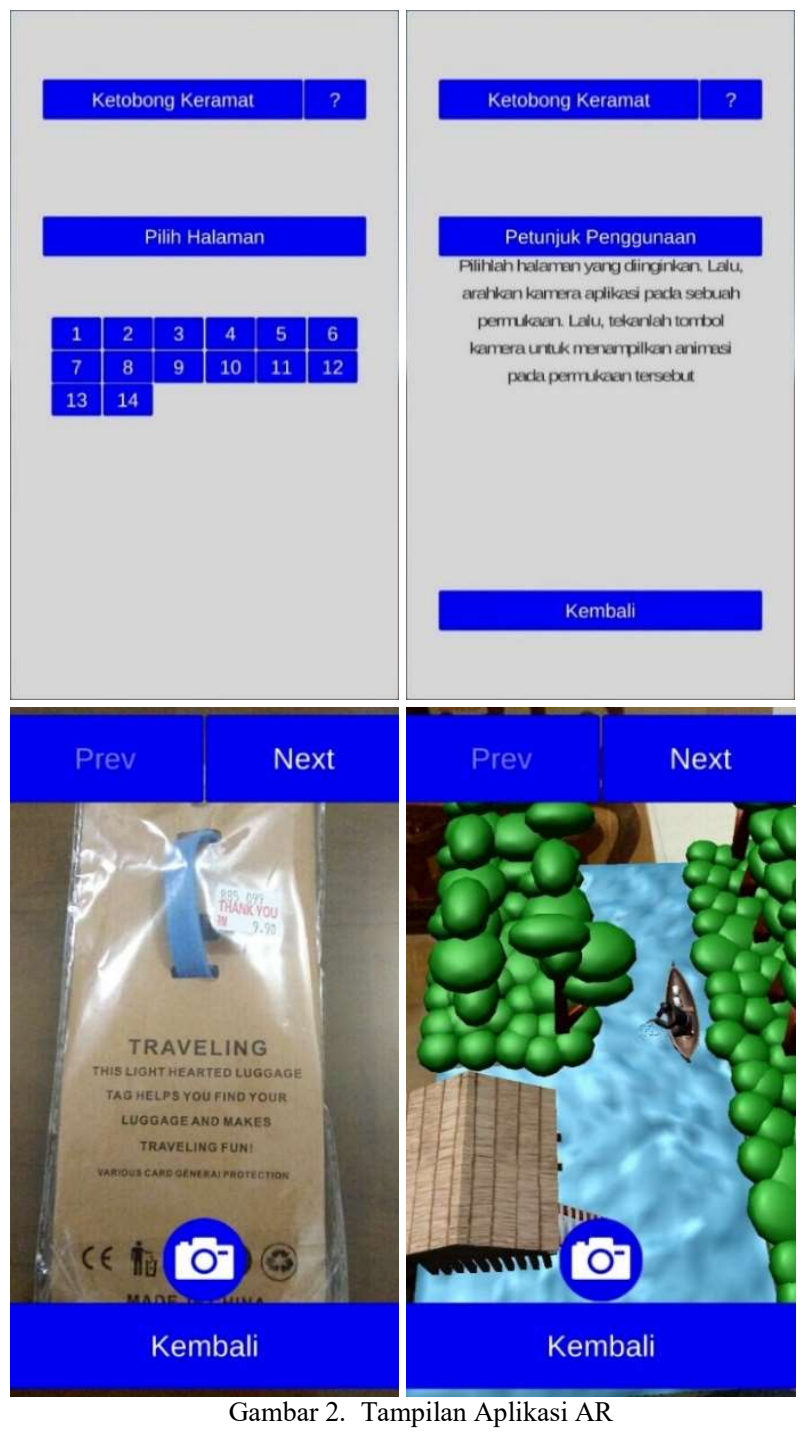

Setelah aplikasi berhasil dikembangkan, maka selanjutnya dilakukan beberapa pengujian sesuai dengan rancangan yang telah dipersiapkan. Pengujian Black Box Testing pada aplikasi Augmented Reality Ketobong Keramat diujikan kepada pengguna yang telah diberikan test case untuk melakukan test fungsionalitas dari aplikasi Augmented Reality Ketobong Keramat. Pengujian ini dilakukan dengan menggunakan smartphone yang telah dipasangkan aplikasi Augmented Reality Ketobong Keramat, dimana hal yang diuji adalah fungsionalitas dari Markerless Augmented Reality yang menggunakan teknik User Defined Target.

Setelah menyelesaikan pengujian, pengguna mengisi test case yang telah disediakan. Pada pengujian ini, aplikasi berhasil menjalankan fungsinya untuk menampilkan animasi ketika tombol kamera ditekan untuk memunculkan animasi. Selain fungsi memunculkan animasi, dilakukan juga pengujian untuk melakukan pergantian permukaan yang dijadikan marker. Setelah mencoba kedua fungsi tersebut, dilakukan pengujian terhadap fungsi Extended Tracking yang merupakan fungsi built-in dari Vuforia SDK yang 
diimplementasikan ke dalam Augmented Reality Ketobong Keramat. Berdasarkan hasil uji tersebut, maka dapat dinyatakan seluruh fungsi yang diberikan oleh aplikasi sudah dapat berjalan dengan baik.

Untuk mengonfirmasi hasil uji fungsional, dilakukan pengujian terhadap umpan balik pengguna, Pengujian Umpan Balik Pengguna dilakukan dengan melakukan tatap muka terhadap 30 orang yang diberikan aplikasi Augmented Reality Ketobong Keramat yang telah dibangun kepada 30 orang responden. Berdasarkan pengumpulan data umpan balik yang telah dilakukan, rangkumannya dapat dilihat pada tabel I.

TABEL I

Hasil Pengujian Umpan Balik Pengguna

\begin{tabular}{|l|c|c|}
\hline \multirow{2}{*}{ Pertanyaan } & \multicolumn{2}{|c|}{ Jawaban } \\
\cline { 2 - 4 } & Ya & Tidak \\
\hline $\begin{array}{l}\text { Apakah animasi dapat ditampilkan pada permukaan } \\
\text { kertas putih? }\end{array}$ & 0 & 30 \\
\hline $\begin{array}{l}\text { Apakah animasi dapat ditampilkan pada tembok } \\
\text { tanpa pattern? }\end{array}$ & 0 & 30 \\
\hline $\begin{array}{l}\text { Apakah animasi dapat ditampilkan pada kertas yang } \\
\text { memiliki gambar, tulisan, atau pattern? }\end{array}$ & 30 & 0 \\
\hline $\begin{array}{l}\text { Apakah aplikasi memerlukan marker khusus untuk } \\
\text { menampilkan animasi? }\end{array}$ & 0 & 30 \\
\hline $\begin{array}{l}\text { Apakah aplikasi dapat menampilkan animasi dalam } \\
\text { wujud Augmented Reality? }\end{array}$ & 30 & 0 \\
\hline $\begin{array}{l}\text { Apakah aplikasi dapat menampilkan animasi pada } \\
\text { permukaan buku cerita rakyat Ketobong Keramat? }\end{array}$ & 30 & 0 \\
\hline $\begin{array}{l}\text { Tanpa menggunakan Extended Tracking, apakah } \\
\text { animasi menghilang ketika kamera diarahkan keluar } \\
\text { dari permukaan yang telah menjadi marker? }\end{array}$ & 28 & 2 \\
\hline $\begin{array}{l}\text { Dengan menggunakan Extended Tracking, apakah } \\
\text { animasi menghilang ketika kamera diarahkan keluar } \\
\text { dari permukaan yang telah menjadi marker? }\end{array}$ & 3 & 27 \\
\hline $\begin{array}{l}\text { Apakah ke-14 halaman dari aplikasi menggambarkan } \\
\text { 14 skenario dari buku cerita rakyat Ketobong } \\
\text { Keramat? }\end{array}$ & 30 & 0 \\
\hline
\end{tabular}

Berdasarkan hasil pengujian yang ditunjukkan pada Tabel I, Maka hampir menyeluruh responden menerima dan setuju dengan pertanyaan untuk aplikasi yang diberikan. Namun masih terdapat beberapa hasil yang kurang mengenai built-in feature yang terdapat pada Vuforia SDK, yaitu Extended Tracking. Sebagian besar responden mengalami kendala ketika mencoba mengubah sudut pandang untuk melihat animasi, dikarenakan animasi menghilang-muncul ketika kamera digerakkan. Sehingga, sebanyak 28 responden menjawab "Ya" untuk pertanyaan ini (93\%), dan 2 responden lainnya menjawab "Tidak" untuk pertanyaan ini. (7\%). Begitu juga pada fitur Extended Tracking, yang berfungsi untuk mempertahankan posisi animasi ketika kamera diarahkan keluar dari permukaan yang sudah menjadi marker. Sebagian besar responden berhasil mengatasi kendala yang terjadi setelah menggunakan fitur ini. Sebanyak 3 responden masih mengalami kendala ini, dikarenakan fitur ini hanyalah membantu aplikasi dalam mempertahankan posisi dari animasi yang telah ditampilkan, bukanlah mendukung sepenuhnya kemunculan animasi secara permanen. Ketiga responden tersebut menjawab "Ya" (10\%). Sementara 27 responden lainnya tidak mengalami kendala, dikarenakan kamera tidak kehilangan pinpoint permukaan yang telah menjadi marker, sehingga memberikan jawaban "Tidak" untuk pertanyaan ini $(90 \%)$.

Pengujian Technical dilakukan dengan melakukan pengujian terhadap kemampuan Markerless Augmented Reality dalam menentukan permukaan untuk memunculkan animasi. Pengujian Markerless Augmented Reality dilakukan terhadap berbagai permukaan datar dengan kontras yang berbeda, dimana beberapa jenis kontras warna permukaan dicoba dengan jenis pencahayaan serta jarak antara 5 hingga $40 \mathrm{~cm}$. skenario dan hasil ujinya dapat dilihat Pada Tabel II berikut.

Pengujian pertama dilakukan dengan kondisi pencahayaan Lampu 20 Watt. Pada pengujian dengan jarak $5 \mathrm{~cm}$, kamera tidak dapat menemukan fokus dikarenakan kurangnya pencahayaan serta jarak kamera yang terlalu dekat dengan objek, sehingga permukaan objek yang dipilih untuk memunculkan Augmented Reality tidak ditemukan. Pengujian dengan jarak $10 \mathrm{~cm}$, kamera berhasil menemukan fokus pada permukaan berwarna dengan kontras bagus, dikarenakan kamera lebih mudah menemukan fokus pada permukaan berwarna serta memiliki kontras yang bagus.

Pada pengujian dengan jarak $20 \mathrm{~cm}$, kamera berhasil menemukan fokus pada keempat jenis permukaan, dikarenakan jarak kamera dengan objek cukup bagus, sehingga kamera dapat mendeteksi permukaan objek yang dipilih dengan mudah. Pada pengujian ini, kamera tetap menemukan kesulitan menemukan fokus pada permukaanpermukaan dengan kontras pattern yang kurang bagus meskipun objek berhasil muncul pada permukaan-permukaan tersebut.

Pada pengujian dengan jarak $30 \mathrm{~cm}$, kamera berhasil mendeteksi permukaan-permukaan yang dipilih penguji dengan cukup mudah, dikarenakan kamera mudah menemukan fokus pada jarak ini.

Pada pengujian jarak $40 \mathrm{~cm}$, kamera tidak berhasil menemukan permukaan yang dipilih oleh penguji dengan baik, dikarenakan pada jarak ini, kamera tidak dapat melakukan fokus lebih jauh lagi, sehingga permukaan yang terdeteksi menjadi lebih dekat daripada permukaan yang seharusnya menjadi target kemunculan animasi. Pada pengujian ini, didapatkan bahwa jarak kamera dengan permukaan objek disarankan tidak melebihi $30 \mathrm{~cm}$ agar mendapatkan hasil yang optimal.

Pengujian kedua dilakukan dengan kondisi pencahayaan Lampu 40 Watt. Pada pengujian dengan jarak $5 \mathrm{~cm}$, kamera tidak dapat menemukan fokus meskipun kualitas dari pencahayaan telah ditingkatkan. Hal ini menandakan bahwa kamera tidak dapat menemukan fokus pada jarak tersebut, meskipun pencahayaan telah ditingkatkan.

Pada pengujian dengan jarak $10 \mathrm{~cm}$, kamera berhasil menemukan fokus pada permukaan dengan kontras yang bagus, baik berwarna maupun permukaan hitam putih. Pada pengujian ini, telah terlihat bahwa pencahayaan mempengaruhi kemampuan kamera dalam mendeteksi permukaan untuk melakukan fokus, sehingga dapat 
TABEL II

Hasil Pengujian TeChNiCAL Kondisi IDEAL

\begin{tabular}{|c|c|c|c|c|c|c|c|c|c|c|c|c|c|c|c|}
\hline & \multicolumn{15}{|c|}{ Jenis Pencahayaan } \\
\hline & \multicolumn{5}{|c|}{ Lampu 20 Watt } & \multicolumn{5}{|c|}{ Lampu 40 Watt } & \multicolumn{5}{|c|}{ Matahari } \\
\hline \multirow{2}{*}{$\begin{array}{c}\text { Kontras Warna } \\
\text { Permukaan }\end{array}$} & \multicolumn{5}{|c|}{ Jarak (cm) } & \multicolumn{5}{|c|}{ Jarak (cm) } & \multicolumn{5}{|c|}{ Jarak (cm) } \\
\hline & 5 & 10 & 20 & 30 & 40 & 5 & 10 & 20 & 30 & 40 & 5 & 10 & 20 & 30 & 40 \\
\hline $\begin{array}{l}\text { Permukaan hitam putih } \\
\text { kontras bagus }\end{array}$ & Tidak & Tidak & $\mathrm{Ya}$ & Ya & Tidak & Tidak & Ya & $\mathrm{Ya}$ & $\mathrm{Ya}$ & Tidak & Tidak & $\mathrm{Ya}$ & $\mathrm{Ya}$ & Ya & Tidak \\
\hline $\begin{array}{l}\text { Permukaan hitam putih } \\
\text { kontras kurang bagus }\end{array}$ & Tidak & Tidak & Ya & Ya & Tidak & Tidak & Tidak & $\mathrm{Ya}$ & $\mathrm{Ya}$ & Tidak & Tidak & $\mathrm{Ya}$ & $\mathrm{Ya}$ & $\mathrm{Ya}$ & Tidak \\
\hline $\begin{array}{l}\text { Permukaan berwarna } \\
\text { kontras bagus }\end{array}$ & Tidak & $\mathrm{Ya}$ & $\mathrm{Ya}$ & $\mathrm{Ya}$ & Tidak & Tidak & $\mathrm{Ya}$ & $\mathrm{Ya}$ & $\mathrm{Ya}$ & Tidak & Tidak & $\mathrm{Ya}$ & $\mathrm{Ya}$ & $\mathrm{Ya}$ & Tidak \\
\hline $\begin{array}{l}\text { Permukaan berwarna } \\
\text { kontras kurang bagus }\end{array}$ & Tidak & Tidak & Ya & Ya & Tidak & Tidak & Tidak & $\mathrm{Ya}$ & $\mathrm{Ya}$ & Tidak & Tidak & $\mathrm{Ya}$ & $\mathrm{Ya}$ & $\mathrm{Ya}$ & Tidak \\
\hline
\end{tabular}

menampilkan objek animasi pada permukaan yang dipilih penguji.

Pada pengujian dengan jarak $20 \mathrm{~cm}$, kamera berhasil menemukan fokus pada keempat jenis permukaan. Perbedaan antara pengujian dengan Lampu 20 Watt dan Lampu 40 Watt terlihat pada pengujian ini, dimana kamera lebih mudah menemukan fokus pada permukaan dengan kontras kurang bagus yang diberikan pencahayaan Lampu 40 Watt, dibandingkan dengan pengujian dengan pencahayaan Lampu 20 Watt. Pada pengujian dengan jarak $30 \mathrm{~cm}$, kamera berhasil menemukan fokus pada permukaan-permukaan yang dipilih penguji. Pada pengujian ini, penguji mencoba menggerakkan kamera tanpa menggunakan fungsi extended tracking untuk melihat pengaruh kemunculan animasi pada keempat jenis permukaan. Pada permukaan dengan kontras kurang bagus, animasi yang ditampilkan akan lebih mudah hilang dibandingkan dengan permukaan yang memiliki kontras warna yang bagus.

Untuk jarak $40 \mathrm{~cm}$, kamera tidak dapat menemukan pemukaan yang dipilih oleh penguji, dimana hasil pengujian ini sama dengan pengujian dengan pencahayaan 20 Watt. Objek yang ditampilkan melayang dari permukaan yang dipilih penguji, dikarenakan permukaan yang dideteksi lebih dekat daripada jarak antara kamera dengan objek. Pengujian ketiga dilakukan dengan menggunakan matahari sebagai pencahayaan terhadap permukaan objek. Pada pengujian dengan jarak $5 \mathrm{~cm}$, kamera tetap tidak dapat menemukan fokus. Pada pengujian ini, ditemukan bahwa pada jarak ini, pencahayaan tidak lagi mempengaruhi kemunculan objek animasi, tetapi ketidakmampuan kamera untuk menemukan fokus pada jarak ini menjadi penyebab objek tidak dapat muncul.

Pengujian dengan jarak $10 \mathrm{~cm}$, kamera berhasil menemukan permukaan-permukaan yang dipilih penguji dengan mudah, meskipun kontras dari permukaan tidak begitu bagus. Pada pengujian ini, disimpulkan bahwa pencahayaan dapat mempengaruhi kemunculan dari suatu objek mulai dari jarak ini. Pada pengujian dengan jarak $20 \mathrm{~cm}$, kamera berhasil menemukan permukaan-permukaan yang dipilih oleh penguji. Pada pengujian dengan jarak ini, dapat ditemukan perbedaan dengan pengujian-pengujian sebelumnya, dimana pada pengujian dengan pencahayaan 20 Watt, kamera kesulitan menemukan fokus. Sementara pada pengujian 40 Watt, kamera lebih mudah menemukan fokus daripada pengujian 20 Watt. Pada pengujian dengan pencahayaan matahari, kamera menemukan fokus lebih cepat dari pengujian-pengujian sebelumnya.

Pada pengujian dengan jarak $30 \mathrm{~cm}$, kamera berhasil menemukan permukaan-permukaan yang dipilih oleh penguji. Pengujian kali ini dilakukan seperti yang dilakukan pada pengujian kedua dengan jarak $30 \mathrm{~cm}$. Hasil pengujian menyerupai hasil pengujian kedua, dimana objek animasi akan menghilang ketika kamera terlalu banyak digerakkan. Hal ini dipengaruhi oleh fungsi pattern recognition kamera untuk mendeteksi permukaan. Sehingga, ketika kamera kehilangan permukaan, maka animasi pun menghilang. Untuk mengatasi hal ini, fungsi extended tracking dapat digunakan untuk mengurangi dampak dari menggerakkan kamera terlalu banyak. Pada pengujian dengan jarak $40 \mathrm{~cm}$, kamera tidak dapat menemukan permukaan yang dipilih oleh penguji, dimana hasil pengujian sama dengan pengujian pada permukaan objek dengan pencahayaan 20 Watt, serta pengujian pada permukaan objek dengan pencahayaan 40 Watt. Objek yang ditampilkan juga melayang seperti yang terjadi pada pencahayaan 40 Watt, meskipun kamera lebih mudah menemukan fokus pada pencahayaan ini.

Berdasarkan hasil pengujian yang telah dilakukan dan ditunjukkan pada table II, maka dapat dinyatakan bahwa, Selain kontrasnya suatu permukaan, jenis pencahayaan yang digunakan juga mempengaruhi kemampuan kamera dalam menentukan permukaan yang dapat dijadikan marker, dimana animasi gagal dimunculkan pada permukaan hitam putih dengan kontras bagus dan jarak $10 \mathrm{~cm}$ dari permukaan objek, serta diberikan pencahayaan dengan menggunakan lampu sebesar 20 Watt. Animasi berhasil dimunculkan dengan kondisi yang sama tetapi dengan pencahayaan yang lebih baik, dimana pencahayaan yang diberikan adalah sebesar 40 Watt. Contoh lainnya adalah dimana objek dapat dimunculkan pada jarak antara 10 hingga $30 \mathrm{~cm}$ pada keempat jenis permukaan dengan menggunakan sinar Matahari sebagai pencahayaan.

Selama melakukan pengujian-pengujian tersebut, durasi waktu yang dibutuhkan aplikasi untuk memunculkan animasi terhitung lebih kurang 1 detik, dan jarak yang ideal untuk memunculkan objek animasi adalah antara 10 hingga $30 \mathrm{~cm}$. 


\section{KESIMPULAN}

Berdasarkan penelitian yang telah dilakukan, maka dapat disimpulkan bahwa Aplikasi telah dibangun menggunakan Blender dan Unity, serta mengimplementasikan Markerless Augmented Reality dengan teknik User-Defined Target. Sehingga dapat menampilkan animasi 3D pada permukaan yang dipilih oleh user tanpa menggunakan marker khusus. Kemampuan aplikasi dalam memunculkan animasi dipengaruhi oleh kontrasnya warna permukaan, pencahayaan, serta jarak kamera dengan objek yang menjadi permukaan dengan kondisi ideal untuk memunculkan animasi adalah dengan menggunakan pencahayaan yang terang menggunakan permukaan dengan kontras warna yang bagus, serta jarak antara objek dengan kamera adalah sejauh 10 hingga $30 \mathrm{~cm}$.

Dalam pengembangan penelitian kedepannya, diharapkan pengembangan User-Defined Target dapat terus meningkatkan kelayakan sebuah pengembangan aplikasi, bukan hanya AR namun juga pada aplikasi multimedia lainnya berbasis mobile, sehingga aplikasi yang dibangun sesuai dengan harapan dari pengguna.

\section{UCAPAN TERIMA KASIH}

Terima kasih kepada seluuh civitas akademika Politeknik Caltex Riau yang telah mendukung pelaksanaan penelitian ini sehingga dapat terselesaikan dengan baik dan tepat waktu.

\section{Daftar Pustaka}

[1] CeritaRakyatNusantara.com, "Cerita Rakyat Nusantara". [Online] http://ceritarakyatnusantara.com/id/article/1-Mewariskan-CeritaRakyat-Nusantara-di-Tengah-Pluralisme-Budaya\#. [Accessed: 12Nov-2018].

[2] CeritaRakyatNusantara.com, "Cerita Rakyat Nusantara". [Online] $\mathrm{http}: / /$ ceritarakyatnusantara.com/id/folklore/27-Ketobong-

Keramat\#. [Accessed: 12-Nov-2018]

[3] A. S. Yoga, "Implementasi Augmented Reality (AR) Pada Fosil Purbakala Di Museum Geologi Bandung," J. Ilm. Komput. dan Inform. (KOMPUTA), 2014.
[4] A. K. Wahyudi, "ARca, Pengembangan Buku Interaktif Berbasis Augmented Reality dengan Smartphone Android," 96 Jnteti, 2014.

[5] D. E. Kurniawan, A. Dzikri, M. Suriya, Y. Rokhayati, and A. Najmurrokhman, 'Object Visualization Using Maps Marker Based On Augmented Reality', in 2018 International Conference on Applied Engineering (ICAE), 2018, pp. 1-5.

[6] R. Gusman and M. E. Apriyani, "Analisis Pemanfaatan Metode Markerless User Defined Target Pada Augmented Reality Sholat Shubuh,” J. INFOTEL - Inform. Telekomun. Elektron., 2016.

[7] M. Jumarlis and M. Mirfan, "Implementation of Markerless Augmented Reality Technology Based on Android to Introduction Lontara in Marine Society," in IOP Conference Series: Earth and Environmental Science, 2018.

[8] R. I. Borman, Y. P. Putra, Y. Fernando, D. E. Kurniawan, P. Prasetyawan, and I. Ahmad, 'Designing an Android-based Space Travel Application Trough Virtual Reality for Teaching Media', in 2018 International Conference on Applied Engineering (ICAE), 2018, pp. 1-5.

[9] D. E. Kurniawan, P. Silalahi, A. Pratiwi, 'ARtrace: Augmented Reality for Students Fine Motor Learning', in 2019 International Conference on Applied Engineering (ICAE), 2019, pp. 1-5.

[10] N. Febrian, H. Setiawan, and O. Hendra Kelana, "Implementasi Augmented Reality Untuk Cerita Rakyat Malin,” no. June, 2016.

[11] I. W. A. Indrawan, I. P. Agung Bayupati, and D. P. S. Putri, "Markerless augmented reality utilizing Gyroscope to Demonstrate the Position of Dewata Nawa Sanga," Int. J. Interact. Mob. Technol., 2018.

[12] A. Aldi, "Aplikasi Pengenalan Hewan dengan Teknologi Marker Less Augmented Reality Berbasis Android," DOUBLECLICK J. Comput. Inf. Technol., 2017.

[13] H. Vitono, H. Nasution, and H. Anra, "Implementasi Markerless Augmented Reality Sebagai Media Informasi Koleksi Museum Berbasis Android (Studi Kasus : Museum Kalimantan Barat)," Univ. Tanjungpura Pontianak, 2016.

[14] D. Kurniawan, A. Rose Irawati, and A. Yuliyanto, "Implementasi Teknologi Markerless Augmented Reality Berbasis Android sebagai Media Pengenalan Gedung-Gedung di FMIPA Universitas Lampung," pp. 95-102, 2015.

[15] T. Hidayat and Nurjayadi, "Aplikasi Mobile Android untuk Pemasaran Perumahan Menggunakan Metode Markerless Augmented Reality pada PT . Alifa Citra Mulia," Apl. Mob. Android untuk Pemasar. Perumah. Menggunakan Metod. Markerless Augment. Real. pada PT. Alifa Citra Mulia, 2015.

[16] Vuforia "User Defined Targets", [Online] https://library.vuforia.com/articles/Training/User-Defined-TargetsGuide [Accessed: 12-Nov-2018].

[17] Berki Rahmat "Analisis dan Perancangan Sistem Pengenalan Bangun Ruang Menggunakan Augmented Reality”, 2011. 